University of Nebraska - Lincoln

DigitalCommons@University of Nebraska - Lincoln

USDA Wildlife Services - Staff Publications

U.S. Department of Agriculture: Animal and Plant Health Inspection Service

May 2020

\title{
Hawaii as a Microcosm: Advancing the Science and Practice of Managing Introduced and Invasive Species
}

\author{
Liba Pejchar \\ Colorado State University - Fort Collins, liba.pejchar@colostate.edu \\ Christopher A. Lepczyk \\ Auburn University \\ Jean E. Fantle-Lepczyk \\ Auburn University \\ Steven C. Hess \\ US Geological Survey Pacific Islands Ecosystems Research Station \\ M. Tracy Johnson \\ he US Department of Agriculture Forest Service \\ Follow this and additional works at: https://digitalcommons.unl.edu/icwdm_usdanwrc \\ Part of the Natural Resources and Conservation Commons, Natural Resources Management and \\ Seficyextpage for additional authorstiol Sciences Commons, Other Veterinary Medicine Commons, \\ Population Biology Commons, Terrestrial and Aquatic Ecology Commons, Veterinary Infectious Diseases \\ Commons, Veterinary Microbiology and Immunobiology Commons, Veterinary Preventive Medicine, \\ Epidemiology, and Public Health Commons, and the Zoology Commons
}

Pejchar, Liba; Lepczyk, Christopher A.; Fantle-Lepczyk, Jean E.; Hess, Steven C.; Johnson, M. Tracy; Leopold, Christina R.; Marchetti, Michael; Mcclure, Katherine M.; and Shiels, Aaron B., "Hawaii as a Microcosm: Advancing the Science and Practice of Managing Introduced and Invasive Species" (2020). USDA Wildlife Services - Staff Publications. 2311.

https://digitalcommons.unl.edu/icwdm_usdanwrc/2311

This Article is brought to you for free and open access by the U.S. Department of Agriculture: Animal and Plant Health Inspection Service at DigitalCommons@University of Nebraska - Lincoln. It has been accepted for inclusion in USDA Wildlife Services - Staff Publications by an authorized administrator of DigitalCommons@University of Nebraska - Lincoln. 


\section{Authors}

Liba Pejchar, Christopher A. Lepczyk, Jean E. Fantle-Lepczyk, Steven C. Hess, M. Tracy Johnson, Christina R. Leopold, Michael Marchetti, Katherine M. Mcclure, and Aaron B. Shiels 


\title{
Hawail as a Microcosm: Advan
the Science and Practice of Managing Introduced and Invasive Species
}

\author{
LIBA PEJCHAR, CHRISTOPHER A. LEPCZYK, JEAN E. FANTLE-LEPCZYK, STEVEN C. HESS, M. TRACY JOHNSON, \\ CHRISTINA R. LEOPOLD, MICHAEL MARCHETTI, KATHERINE M. MCCLURE, AND AARON B. SHIELS
}

\begin{abstract}
Invasive species are a leading driver of global change, with consequences for biodiversity and society. Because of extraordinary rates of endemism, introduction, and extinction, Hawaii offers a rich platform for exploring the cross-disciplinary challenges of managing invasive species in a dynamic world. We highlight key successes and shortcomings to share lessons learned and inspire innovation and action in and beyond the archipelago. We then discuss thematic challenges and opportunities of broad relevance to invaded ecosystems and human communities. Important research needs and possible actions include eradicating mammals from mainland island sanctuaries, assessing hidden threats from poorly known introduced species, harnessing genomic tools to eradicate disease vectors, structured decision-making to achieve common objectives among diverse stakeholders, and enhancing capacity through nontraditional funding streams and progressive legislation. By shining a spotlight on invasive species at the front lines in Hawaii, we hope to catalyze strategic research and practice to help inform scientists and policymakers.
\end{abstract}

Keywords: Hawaiian Islands, invasion biology, invasive exotic species, biodiversity conservation, ecological restoration

Intrison nvasive species have well-documented and transformative effects on species and ecosystems (Lockwood et al. 2013). A subset of species that are introduced outside of their native range intentionally or accidentally become invasive, with negative impacts on nature and society. Invasion can lead to species extinction and undermine the provision of ecosystem services (Pejchar and Mooney 2009), with important consequences for native species diversity (Vila et al. 2011), human health (Crowl et al. 2008), and economic vitality (Pimentel et al. 2005). The spread and establishment of nonnative species is likely to continue, if not increase, in a world of widespread global trade and climate change (Lockwood et al. 2013). Considering these trends in conjunction with limited conservation dollars (Murdoch et al. 2007) and the universal challenges of prevention, eradication, and control (Mack et al. 2000), we argue that it is both urgent and strategic for scientists and policymakers to examine invasive species hotspots (Dawson et al. 2017) to identify lessons learned.

The Hawaiian Islands are a useful model system for evaluating the successes and shortcomings of managing diverse dimensions of introduced and invasive species (Vitousek et al. 1987). Given the susceptibility of its flora and fauna to past and ongoing invasion (Sakai et al. 2001), Hawaii could be considered a sentinel of change. Globally, the Hawaiian Islands are in the top three regions housing the highest richness of established nonnative species (Dawson et al. 2017). Over 1000 species of plants (Wagner et al. 1999), 3000 arthropods (Nishida 2002), approximately 57 birds (Moulton and Pimm 1983), 15 mammals (Vitousek et al. 1987), and more than 37 species of freshwater fish (Yamamoto and Tagawa 2000) have become established in Hawaii. Although only a small fraction of introduced species are invasive, those invasive species are now a leading driver of biodiversity loss and habitat degradation (Daehler et al. 2004). Hawaii's unfortunate legacy offers a unique lens for examining the transformative effects of invasive species and attempts to mitigate those impacts on islands rich in natural and cultural heritage.

Hawaii's response to introduced and invasive species has been fraught with challenges, but the state has also achieved some remarkable successes. We suggest that Hawaii can serve as a model for other islands and mainland systems that face similar issues. Our objective is to share the islands'

BioScience 70: 184-193. ( The Author(s) 2020. Published by Oxford University Press on behalf of the American Institute of Biological Sciences. All rights reserved. For Permissions, please e-mail: journals.permissions@oup.com. 
successes, shortcomings, and emerging challenges with invasive species management to catalyze both science and practice and to sustain native biodiversity and human wellbeing in a changing world.

\section{Success stories}

The preponderance of invasive species in Hawaii often leads to a perception that there is little hope of managing them. In fact, Hawaii has had a number of successes both in management and in policy that stand out as examples for other islands and continental systems (figure 1). Among the successes, the following examples are particularly notable and broadly relevant.

Benjamin Franklin's famous words "An ounce of prevention is worth a pound of cure" summarize what biologists have long known about critical timing for interventions against invasive species. A case in point for Hawaii is the brown tree snake (Boiga irregularis). Following its establishment on Guam in the early 1950s, the brown tree snake extirpated 10 of 13 native bird species, caused major economic losses, including electrical power outages, and is an ongoing human health risk (Shwiff et al. 2010). Rigorous interdiction and surveillance methods are the main components of an extensive program established to prevent dispersal of the brown tree snake outside of Guam to Hawaii and other islands susceptible to invasion (Engeman and Vice 2001). Although Hawaii greatly benefits from Guam's safeguards, Hawaii also has one of the most active programs to control and contain inbound brown tree snakes. Although snakes have been detected in Hawaii arriving in cargo (Hawaii Invasive Species Council 2019), there is no evidence that this species has established, demonstrating that relentless and targeted efforts to exclude noxious invaders can be successful (Engeman and Vice 2001). If brown tree snakes were to become established in Hawaii, the economic damage caused by the loss of tourism, medical treatment for snake bites, and snake-caused power outages would result in a potential annual cost to the state between $\$ 593$ million and $\$ 2.4$ billion (Shwiff et al. 2010). By considering the extraordinary risk that invasive species such as the brown tree snake poses to the economy, environment, and human health, Hawaii has demonstrated that prevention can be a strategic investment.

Although Hawaii has active interdiction programs at ports of entry, new species still enter the state at high rates every year (Lockwood et al. 2013). Invasive species committees, established on all islands by 2001, have launched numerous early-detection campaigns (Loope et al. 2013). As a result of these efforts, including substantive investment into personnel trained to address early incursion, Hawaii has successfully stopped or limited the permanent establishment of a number of species (Kraus and Duffy 2010). For example, rapid response teams effectively halted the establishment of covertly released axis deer (Axis axis) on Hawaii Island (Hess et al. 2015), the veiled chameleon (Chamaeleo calyptratus) on Maui (Holland et al. 2018), and the small Indian mongoose (Herpestes javanicus) on Kauai (Wostenberg et al. 2019). Similarly, the eradication of at least a dozen incipient invasive plant species on Maui, Lanai, and Molokai Islands has been successful through the sustained efforts of trained field crews and cooperative property owners (Penniman et al. 2011). A coordinated and collaborative network of invasive species prevention groups can be highly effective in detecting and eradicating incipient invasions.

If nonnative species establish and become invasive, a different set of tools is required to manage them. Biological control using intentionally introduced, host-specific natural enemies provides a tool that can be effective and persistent at broad spatial scales. During more than a century of biocontrol, Hawaii has seen hundreds of planned introductions of natural enemies. These introductions have been focused primarily on agricultural pests, and there are many noteworthy successes, such as the suppression of the rangeland weeds prickly pear (Opuntia spp.) and lantana (Lantana camara) (Conant et al. 2013). Unfortunately, early biocontrol programs also had harmful effects on nontarget native species, including impacts by generalist natural enemies on Hawaiian Lepidoptera (Henneman and Memmott 2001). Using biosecure facilities and rigorous screening, careful targeting of invasive species with more specialized enemies has resulted in safer use of biocontrol, and nontarget impacts have been completely avoided since the 1970s (Reimer 2002). In the subsequent four decades, protection of native ecosystems against aggressive invaders has become a primary goal of Hawaiian biocontrol research (Smith 2002), with priorities set by agencies working together at island and watershed scales (Loope et al. 2013). Biocontrol successes include suppression of the invasive vine banana poka (Passiflora tarminiana) in native forests (Trujillo et al. 2001) and an invasive gall wasp that threatened extirpation of the native tree wili wili (Erythrina sandwicensis) (van Driesche et al. 2016). Biocontrol is widely recognized among Hawaii conservationists as a critical tool for sustaining management of disruptive invaders, such as strawberry guava (Psidium cattleianum) and miconia (Miconia calvescens) (Johnson 2010, 2016). However, because these species are only a few of the many dozens of invasive plants that threaten native ecosystems, and given the years of effort typically required for each project, it is essential in targeting biocontrol efforts to prioritize the most damaging invaders while also pursuing expansion of biocontrol research capacity (Smith 2002, van Driesche et al. 2016).

Although biocontrol is generally not practical for invasive mammals, whole-island management can be possible using other tools. Hawaii has a long tradition of eradicating mammals from small islands. In 1923, hunters eradicated rabbits (Oryctolagus cuniculus) on Laysan Island, where the animals had been intentionally introduced and had reduced the vegetated island to barren sand, causing the local extinction of 22 plant species and three endemic land birds through habitat loss (Watson 1961). In recent years, invasive rats have become targets of eradication on small islands using 
Invasive Species
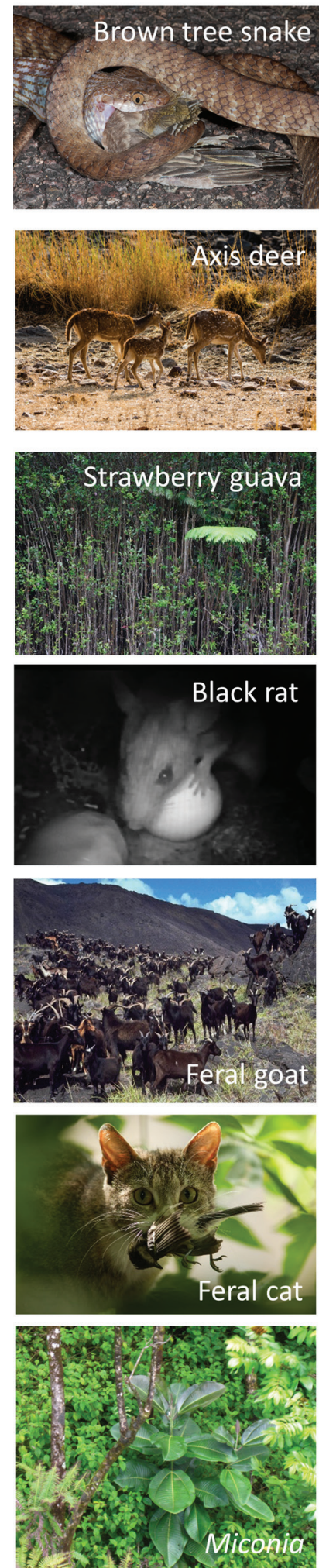

\section{Strategies}
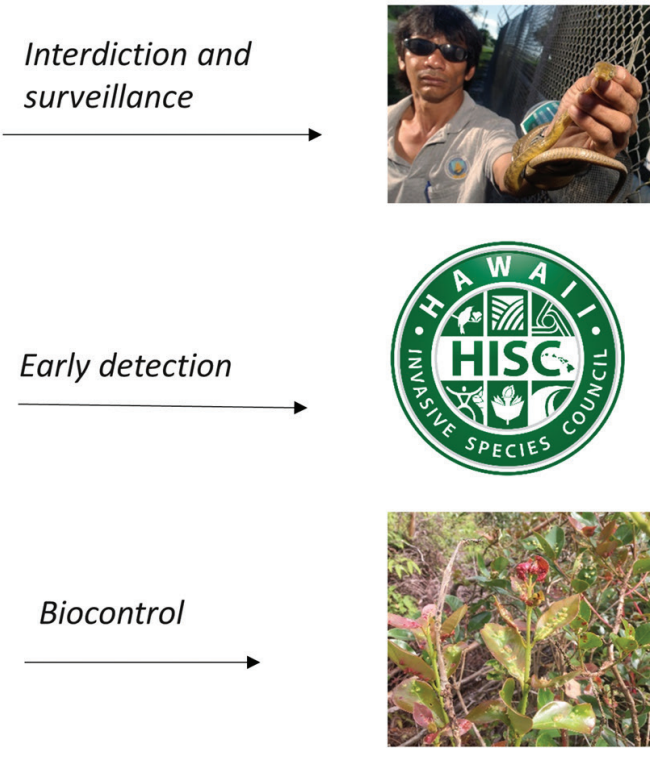

Whole island eradication

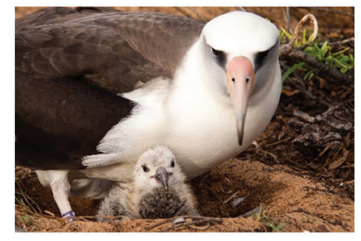

Ungulate fencing
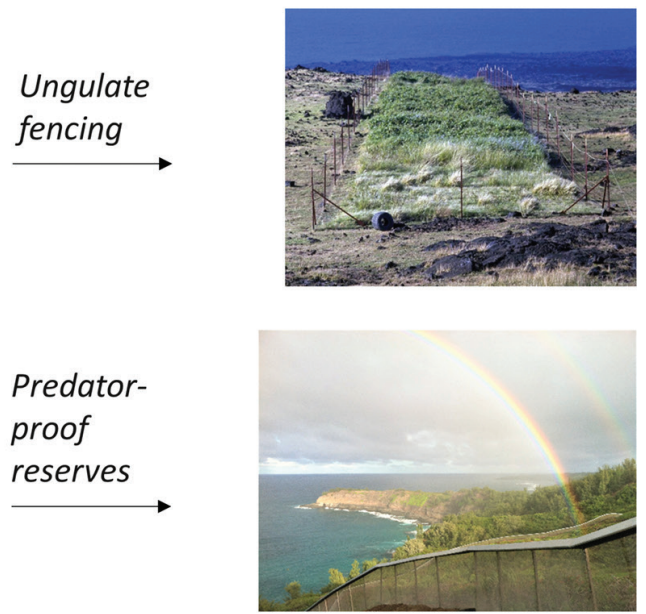

Herbicide ballistic technology

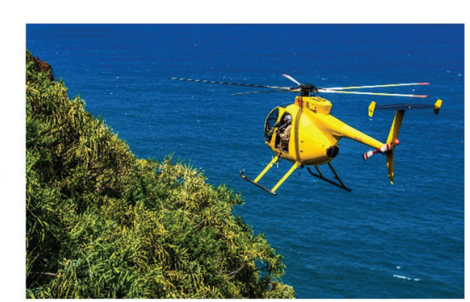

Figure 1. Hawaii has been a pioneer in invasive species management. This figure illustrates how Hawaii has developed or field tested novel responses to the threat of invasive species at all stages: transport (brown tree snake), colonization (axis deer), establishment (black rat), and spread (strawberry guava, feral goat, feral cat, miconia). Photographs (clockwise from top left): Stewart McDonald, USDA, HISC, USDA Forest Service, dsischo, NPS Don Reeser and Bryan Harry, Pacific Rim Conservation, Daniel Sullivan, Josh Atwood, ornitolog82, NPS Don Reeser and Bryan Harry, Island Conservation, Jack Jeffrey, D Mzfrom Pixabay. 
methods imported from New Zealand. For example, black rats (Rattus rattus) and polynesian rats (Rattus exulans) were fully removed from two islands adjacent to Oahu, as well as Midway Atoll (Hess and Jacobi 2011), whereas eradication efforts are underway on Lehua Island. In addition, Mokapu, off the north shore of Molokai, has the first and only successful eradication of invasive rats via aerial broadcast of rodenticide in Hawaii. Whole-island eradication of larger invasive mammals is possible under some circumstances (e.g., islands that are relatively small and where topography and vegetation are less complex, making eradication more feasible). For instance, goats (Capra hircus) have been removed from Niihau, Lanai, and Kahoolawe, sheep (Ovis aries) from Kahoolawe, and pigs (Sus scrofa) from Lanai (Hess and Jacobi 2011).

When island-wide eradication of invasive mammals is unfeasible because of island size, topography, habitat complexity, or lack of public support, the construction of fences to exclude mammals from ecologically important areas is often used. Following New Zealand's pioneering lead (Burns et al. 2012), Hawaii has built predator-proof "islands" to protect important seabird colonies and tree snails. These fenced reserves have several features to prevent incursion from predators climbing over or burrowing under, including an overhanging hood, fine mesh, and a buried skirt. Hawaii's first predator-proof fence (622 meters) was constructed in 2011 at Kaena Point, Oahu (Young et al. 2013). Subsequent predator-proof fences have been erected on Maui, Kauai, and Oahu in addition to the longest predator proof fence in the United States, an 8-kilometer cat-proof fence enclosing 42 hectares in Hawaii Volcanoes National Park. Each fence was constructed to protect breeding seabirds, to enable the establishment of new seabird breeding populations naturally or by translocation, or to allow the reintroduction and regeneration of native plants and tree snails. Record numbers of Laysan albatross (Phoebastria immutabilis) and wedge-tailed shearwater (Puffinus pacificus) chicks have fledged since predators were eradicated from the Kaena Point fenced reserve, and native plants have exhibited strong recovery (Young et al. 2013).

Fences have also been successfully used to exclude ungulates such as goats and sheep from large areas. Several ungulate species were brought to Hawaii by Captain James Cook in 1778. These ungulates repeatedly escaped captivity and persisted even in arid environments (Hess and Jacobi 2011), leading to deforestation, soil erosion, and altered nutrient cycling (Leopold and Hess 2016). Hawaii pioneered methods to eradicate goats from national parks by establishing fenced areas of manageable size and applying the Judas goat technique, which uses radio telemetry to take advantage of gregarious behavior in domestic ungulates (Hess and Jacobi 2011). The eradication of goats from 554 square kilometers $\left(\mathrm{km}^{2}\right)$ of Hawaii Volcanoes National Park (1968-1984) and $137 \mathrm{~km}^{2}$ of Haleakala National Park (1983-1989) are among the largest goat removal efforts on Pacific islands (Hess and Jacobi 2011). Goat control in Hawaii's national parks demonstrated the technical feasibility of eradicating ungulates from large areas and resulted in techniques such as Judas goats that have been successfully applied throughout the world (Campbell and Donlan 2005). Ungulate fences combined with snaring and hunting have also been used to eradicate invasive pigs from ecologically important areas on Oahu, Maui, and Hawaii Islands. Through these extraordinary efforts, ungulates have now been removed from more than $750 \mathrm{~km}^{2}$ in Hawaii (Hess and Jacobi 2011).

One persistent obstacle to invasive species control in Hawaii, as well as in many other locations around the world, is challenging topography. Steep and rugged slopes and high elevations serve as refugia for invasive species as these areas are exceptionally difficult for people to access. Several new technologies have been game changers for managing invasive species in difficult terrain in Hawaii. For example, nighttime infrared scopes and forward-looking infrared cameras were deployed via helicopters and used to locate axis deer for eradication on Hawaii Island (Hess et al. 2015). Similarly, herbicide ballistic technology (HBT) is a novel, highly efficient weed control tool designed and tested in Hawaii to pneumatically deliver encapsulated herbicide projectiles onto individual invasive plants. Developed from recreational paint ball guns, HBT has been deployed both from the ground and helicopters for effective rapid-response control during aerial surveillance of incipient invasive plant populations, such as M. calvescens (Leary et al. 2013). Another recent technology imported from New Zealand is the self-resetting kill trap (e.g., Goodnature A24), which has the potential to be 20 times more effective at removing rats than any other available trapping method. Although trap improvements continue, these new traps offer the possibility of efficiently suppressing rat populations by reducing the effort required to service traps, especially in remote and steep lands (Shiels et al. 2019).

Other technological advances have helped identify and control invasive species over large geographic areas and in marine environments. For example, new methods of remote sensing have been developed in Hawaii, such as laser-guided imaging spectroscopy used to build high resolution maps and guide management of rapid ohia death (ROD), an aggressive new fungal disease of Hawaii's dominant native tree ohia lehua (Metrosideros polymorpha) (Vaughn et al. 2018). Finally, just as terrestrial areas can be remote and difficult to access, removing invasive species from oceanic environments is technically challenging. Hawaii has been a pioneer in pairing a powerful underwater vacuum cleaner (the "super sucker") with biocontrol (urchins) to reduce cover of an invasive alga (Gracilaria salicornia) on coral reefs by $85 \%$ (Neilson et al. 2018). Vacuumed algae are then used to fertilize local crops.

Aside from on-the-ground management, Hawaii has also been a leader in advancing invasive species control through legislation driven by needs identified through innovative partnerships. A significant turning point was the establishment of the Hawaii Invasive Species Council (HISC) in 2003 
(Loope et al. 2013). Hawaii's state legislature created HISC "to provide policy level direction, coordination, and planning among state departments, federal agencies, and international and local initiatives for the control and eradication of harmful invasive species infestations throughout the State and for preventing the introduction of other invasive species that may be potentially harmful." The state legislature funded HISC via a tax that provides an annual allotment for invasive species management and research. A second recent advancement was the establishment of the 2017-2027 Hawaii Interagency Biosecurity Plan (https://hdoa.hawaii. gov/wp-content/uploads/2016/09/Hawaii-InteragencyBiosecurity-Plan.pdf). Developed over several years through workshops, public hearings, and agency meetings, the plan's vision is to protect the state's economy and ecosystems from the impacts of introduced species. Both the planning process and outcomes represent models for other states and governments to work toward for invasive species management.

\section{Shortcomings}

As is illustrated by its success stories, Hawaii has made significant advances in the science and practice of controlling invasive species. However, not all efforts have been successful and it is critical to understand and avoid past pitfalls to make better-informed decisions in the future. Notably, many failed approaches started with good intentions or were based on the best available science at the time of the decision.

Setting aside large tracts of protected land has been a cornerstone of conservation globally. However, simply setting aside land fails catastrophically in Hawaii without substantial additional intervention. Because of the large number of nonnative species, the tropical climate, and the susceptibility of endemic species to novel forms of predation, herbivory, and disease, designating reserves is not enough to sustain native biodiversity (Vitousek et al. 1987). Such protected areas are not dissimilar to parks that exist in name only (Bruner et al. 2001). For example, of all stateowned lands, only natural area reserves $(9.5 \%$ of land managed by the Department of Land and Natural Resources) are actively managed first and foremost for native species (Hawaii Division of Forestry and Wildlife 2018). As a result, Hawaii's forests may appear lush and vibrant, but many are dominated by high densities of nonnative plants (Mascaro et al. 2012). In the absence of active management (e.g., weed and disease control, eradication of invasive herbivores and predators), invasive ungulates graze on native plants, feral cats and rats depredate native birds, and diseases carried by invasive mosquitoes further devastate native avifauna (Atkinson et al. 2000). Invasive species therefore degrade protected forests directly and indirectly, often in ways that are largely invisible to policymakers and the public. In contrast, protected areas that are actively managed for native plant and animal communities (e.g., invasive species control paired with large-scale native forest restoration) are some of the only places where the trends appear positive for Hawaii's threatened native species (Camp et al. 2010).
Funding is a limiting factor at all stages of invasive species management in Hawaii, inhibiting improvements in early detection, rapid assessment, and ongoing control. For example, although inspection and quarantine systems are in place, logistics and funding limit Hawaii's ability to inspect more than a small proportion of incoming goods. New species arrive in Hawaii through diverse pathways (e.g., purposeful introductions, escaped cultivars or pets, on horticultural materials, in cargo holds), and the rate of new or repeated introductions has increased exponentially. For instance, the prehistoric dispersal rate of one plant species every 100,000 years accelerated to one new plant species every 50 years after the arrival of Polynesians and to 22 new species per year after the arrival of Europeans (Lockwood et al. 2013). But much of the traffic entering Hawaii currently goes uninspected, including materials such as postal shipments and import cargo, known to be significant sources of new introduced species (DeNitto et al. 2015). Although an argument can be made that more funding is always needed, given the economic impact of invasive species across the United States (Pimentel et al. 2005), the disconnect between need and availability of funds for mitigating invasive species is troubling. One solution that has been proposed is to impose an arrival fee or hotel tax to increase awareness and the funding base for invasive species control in a tourism-driven economy.

Compounding the problem of financial shortcomings is the lack of recognition of most invasive species issues by tourists and residents, which leads to low prioritization by policymakers. For instance, even though there has been an increase in awareness of invasive species over the past decade and the majority of residents consider invasive species as a serious problem, it still ranks near the bottom of current environmental issues among the public (Coordinating Group on Alien Pest Species 2017). Furthermore, residents can readily identify only a handful of well-known invasive species and most (59\%) cannot identify a single native forest bird (Coordinating Group on Alien Pest Species 2017). As in the rest of the world, most people now live in cities, resulting in a strong disconnect with nature for more urban residents (Luck et al. 2011). When media and outreach efforts do focus on invasive species, they often target only one or two species and tend to present both sides of the story, including the perspectives of small but vocal groups of supporters of some invasive species (Warner and Kinslow 2013). Limited public awareness coupled with lean state budgets means there is little incentive for policymakers to advocate for major changes in invasive species funding and regulations.

Stakeholder conflicts can pose a significant impediment to invasive species management. Particularly problematic is the longstanding disagreement over subsistence and recreational hunting of large game animals, all of which are nonnative and incompatible with conservation of native biota and watershed function in Hawaii and many other island systems (Leopold and Hess 2016). Management actions for conservation generally exclude ungulates from natural areas, which reduces the amount of land area 


\begin{tabular}{|c|c|}
\hline Emerging challenges & Central questions \\
\hline $\begin{array}{l}\text { Increasing prevalence of novel } \\
\text { ecosystems }\end{array}$ & $\begin{array}{l}\text { Under what circumstances should we manage against, tolerate, or manage for, ecosystems with } \\
\text { established populations of nonnative species? }\end{array}$ \\
\hline Increasing commerce and trade & $\begin{array}{l}\text { Where should efforts be directed to keep nonnative species entry rates from increasing with commerce } \\
\text { and trade? }\end{array}$ \\
\hline $\begin{array}{l}\text { The paradox of invasive endangered } \\
\text { species }\end{array}$ & $\begin{array}{l}\text { How do we decide whether to eradicate or sustain populations of invasive species that are endangered } \\
\text { in their native ranges? Should invasive endangered species be removed and relocated to their native } \\
\text { range or managed in an ex situ context? }\end{array}$ \\
\hline $\begin{array}{l}\text { Many introduced species are } \\
\text { presumed benign }\end{array}$ & $\begin{array}{l}\text { Given limited resources, how can we use traits or other rapid-assessment tools to avoid missing cryptic } \\
\text { ecological impacts of introduced species on native communities? }\end{array}$ \\
\hline $\begin{array}{l}\text { Introduced pathogens require rapid } \\
\text { responses }\end{array}$ & $\begin{array}{l}\text { How should we deploy self-sustaining vector control methods in complex landscapes with diverse } \\
\text { stakeholders? }\end{array}$ \\
\hline $\begin{array}{l}\text { The possible synergistic effects of } \\
\text { climate change }\end{array}$ & $\begin{array}{l}\text { How do we incorporate the uncertainty associated with climate change scenarios into long-term planning } \\
\text { for invasive species prevention and control? }\end{array}$ \\
\hline $\begin{array}{l}\text { Managing invasive species for nature } \\
\text { and human health }\end{array}$ & $\begin{array}{l}\text { Under what circumstances could applying ecological interventions to reduce disease risk be more } \\
\text { effective than traditional public health or conservation interventions? }\end{array}$ \\
\hline $\begin{array}{l}\text { Balancing management strategies } \\
\text { with public opinion that favors } \\
\text { retaining some invasive species }\end{array}$ & $\begin{array}{l}\text { How can management strategies such as control and eradication of invasive species be effectively } \\
\text { balanced when some species are favored by residents (e.g., game animals, songbirds, exotic plants, and } \\
\text { reptiles)? }\end{array}$ \\
\hline
\end{tabular}

available for hunting. However, planning to accommodate sustained yield hunting of most game species has been notably lacking (Hess and Jacobi 2014). Year-round bag limits are generally set without regard for abundance, recruitment, or any other information on population dynamics (Ikagawa 2013). Furthermore, hunter education programs promote mainland values such as limited harvest of females (Lepczyk et al. 2011). Feral pigs are the most abundant and popular species for subsistence and recreational hunting in Hawaii, and they are also culturally and socially important because of their traditional mythological symbolism in the Hawaiian legend of Kamapuaa, the hog child demigod (Wehr et al. 2018). However, large mammal hunting was not an ancient traditional practice; instead, recreational hunting became popular after World War II (Duffy 2010). Consequently, relatively recent societal values that favor game production also require the construction and maintenance of expensive barriers to exclude overabundant animals from conservation areas (Hess and Jacobi 2014).

Demonstrating success in any management action requires ongoing monitoring. However, in the case of invasive species control, such assessments are often absent or limited because of insufficient resources. For example, $38 \%$ of 136 island rat control projects occurring globally have not assessed if rat control efforts were effective (Duron et al. 2017). Furthermore, $42 \%$ of these projects did not monitor native species response to management interventions. Without monitoring, the success of invasive species control or eradication is very difficult to assess beyond anecdotal observations. Moreover, invasive species removal can have unforeseen impacts associated with ecological release. After long-term removal of pigs from a forested area on Hawaii Island, the density of strawberry guava, an invasive woody plant, increased fivefold (Cole et al. 2012). Incorporating a BACI design (before, after, control, impact) as standard practice would be beneficial. Without monitoring, few lessons are learned from invasive species control and evidence-based decisions are impossible.

\section{Emerging issues, questions, and opportunities that resonate beyond Hawaii}

In addition to serving as a model of successes and shortcomings in invasive species management, Hawaii has also been a launch pad for exploring future challenges and opportunities. The following concepts and questions emerged in large part from Hawaii's experience but resonate far beyond this archipelago (table 1).

Hawaii has been an exemplar for the novel ecosystems concept (Hobbs et al. 2009). For instance, Hawaii's lowland forests are predominately a dynamic mix of native and nonnative species, which presents a novel assortment of species relative to those that have existed previously (Mascaro et al. 2012). Through the novel ecosystems lens, these relatively new communities are an opportunity to advance understanding of species assembly, competition, and ecosystem function (Cordell et al. 2016). But conservation biologists are split on the value and validity of novel ecosystems (Truitt et al. 2015). Some embrace them as inevitable byproducts of human-dominated ecosystems that challenge us to rethink historical restoration targets and traditional conservation interventions (Hobbs et al. 2009), whereas others reject them as a distraction from the primary goal of sustaining and restoring habitat for imperiled endemic species (Murcia et al. 2014). Because of the pervasive establishment of introduced and invasive species, Hawaii and other islands are model systems for exploring if and how to act on the novel ecosystems concept. Perhaps the most important question is under what circumstances do you manage against, tolerate, or manage for ecosystems with established populations of nonnative species (Truitt et al. 2015)? 
Encountering taxa that are simultaneously endangered and invasive is increasingly commonplace. This duality arises when a nonnative species is established in a novel location but is concomitantly endangered in its native range (Marchetti and Engstrom 2016), creating a dilemma in which efforts to protect the invaded ecosystem and its complement of native taxa conflict with the protection of the endangered species. Such a situation occurs in Hawaiian streams where the wattle-necked softshell turtle (Palea steindachneri; Marchetti and Engstrom 2016) is invasive, but endangered in its native habitats of South China and Vietnam. With the rapid increase in global trade and simultaneous decline in endemic species, we expect the paradox of invasive endangered species to emerge as an increasingly common challenge to conservation scientists and practitioners on both island and continental systems.

Hawaii is dominated by introduced species, many of which are perceived as having few negative impacts on nature or society. However, the view that many long-established introduced species pose little to no risk to ecosystems (e.g., Davis et al. 2011) is problematic. The reality is that the impact of many introduced species remains poorly understood. For instance, Jackson's chameleons (Trioceros jacksonii) were not considered invasive until recent work demonstrated they consume endemic endangered tree snail species (Chiaverano and Holland 2014). Across Hawaii there are a wide variety of upland game birds, parrots, herpetofauna, aquarium fish, and ornamental plants that have never been evaluated in terms of their effects on ecosystems. This is particularly true for freshwater ecosystems, possibly because the native diversity is somewhat low and aquatic fauna are small and not particularly charismatic. Over 70 nonnative taxa have been introduced to Hawaii's streams and rivers, some of which are top predators (e.g., largemouth bass, Micropterus salmoides; Yamamoto and Tagawa 2000). The lack of evaluation of many introduced species is surprising, because ecologists have long understood that any addition or subtraction to a system could be expected to affect energy and nutrient flux, and trophic interactions. Therefore, to willfully consider many species benign with no ecological evaluation unnecessarily increases the threat of invasional meltdown in the many ecosystems with introduced species globally (Simberloff and Von Holle 1999).

Introduced plant and wildlife pathogens pose substantial threats to native biodiversity, requiring rapid and innovative disease management responses. Two introduced fungal species that cause ROD in $M$. polymorpha have killed hundreds of thousands of trees on Hawaii Island (Barnes et al. 2018). Rapid, targeted management actions, including public outreach and education, monitoring disease spread through remote sensing and molecular diagnostics, and an embargo on movement of $M$. polymorpha and soil have successfully slowed the spread of ROD to other Hawaiian islands (Atkinson et al. 2017). Another introduced disease affecting native species is avian malaria, a mosquito-borne disease associated with ongoing population declines and increased extinction risks in native Hawaiian birds (Atkinson et al. 2000). Novel vector control methods that target the primary vector of avian malaria in Hawaii, the southern house mosquito (Culex quinquefasciatus), hold promise as a means to reduce avian malaria transmission to susceptible native birds (Paxton et al. 2018). Non-genetically modified approaches are currently being pursued, including the release of male mosquitoes artificially infected with a naturally occurring Wolbachia strain that impedes reproduction and suppresses mosquito populations (Atyame et al. 2015). In addition, some Wolbachia strains $(w \mathrm{Mel})$ inhibit the replication of dengue and other arboviruses in Aedes species (Blagrove et al. 2012). Successful field trials in Australia and elsewhere suggest that a program in Hawaii targeting Aedes albopictus-an invasive mosquito species recently implicated in locally transmitted dengue outbreaks in Hawaii (Johnston et al. 2016) — could reduce Ae. albopictus vector competence for emerging arboviruses in Hawaii.

Other vector control methods are being explored that use gene drive techniques to spread genome edits through the vector population that reduce disease transmission or suppress mosquito populations (Alphey 2014). Challenges with both genetically and non-genetically modified vector control include increasing mass mosquito rearing capacity, deploying vectors across topographically complex landscapes, and developing robust monitoring tools (Paxton et al. 2018). In all cases, implementing an effective community engagement strategy is paramount. Despite such challenges, novel vector control methods represent pioneering approaches for introduced disease management, with potential benefits for native biodiversity and human health.

Climate change adds complexity and challenge to invasive species management in Hawaii and beyond. Much global research to date has focused on predicting how invasive species distributions will change in relation to climate (Peterson 2003). Evidence suggests that invasive species are shifting ranges poleward, upward in elevation, and that invasive species ranges may expand more rapidly than native species (Lockwood et al. 2013). The shifting of ranges up in elevation is of particular concern in Hawaii, especially as invasive mosquitoes and avian malaria move upslope, contributing to the collapse of the native forest bird community on lower elevation islands (Atkinson et al. 2014, Paxton et al. 2016). Globally, there is already a reshuffling of species as ranges shift, resulting in no-analog species assemblages and possible changes in ecosystem function. For example, fire-adapted invasive grasses are expanding into high elevations in Hawaii (Angelo and Daehler 2013). Climate change could also enable other, previously noninvasive species to become invasive (Lockwood et al. 2013). On the other hand, some species invasive in Hawaii and beyond, such as $M$. calvescens, are predicted to contract in range under various climate scenarios (González-Muñoz et al. 2015). Ultimately, the uncertainty associated with alternative future climate change scenarios poses challenges to long-term planning for invasive species prevention and control. 
Links between invasive species, native biodiversity, and human well-being offer opportunities for management actions that benefit both people and nature, as is embodied in the One Health perspective. A case in point is the recent emergence in Hawaii of angiostrongyliasis, a debilitating disease in humans caused by an introduced nematode Angiostrongylus cantonensis. Rats (Rattus spp.) are the definitive hosts of $A$. cantonensis, shedding larvae in their feces when infected, which are, in turn, ingested by gastropod hosts (Hollingsworth et al. 2013). People become infected by accidently consuming infected gastropods. Reducing rat abundance at low elevations on Hawaii Island where most angiostrongyliasis cases originate (Jarvi et al. 2015) and where some native birds persist in moderate abundance (Woodworth et al. 2005) could decrease angiostrongyliasis risk in humans and nest depredation rates in native birds concurrently. A second example of potential synergies between invasive species control for nature and people is vector control. $C x$. quinquefasciatus co-occurs with Ae. albopictus below approximately 900 meters, and the abundance of both mosquito species increases with development and residential land use in lowland Hawaii (McClure et al. 2018). Mosquito control could benefit both people and native biodiversity in low- to mid-elevation areas of Hawaii where native birds persist in fragmented forests in proximity to residential areas at heightened risk for dengue outbreaks. Employing such ecological interventions would require data on the distribution and abundance of target populations, an understanding of the spatial and temporal scale at which interventions will be most effective, and a rigorous assessment of the costs versus benefits of using these techniques relative to more traditional public health or conservation interventions.

\section{A strategic path forward}

Hawaii, like most places, has limited resources to devote to controlling invasive species. How do decision-makers decide what proportion of these resources to devote to prevention, eradication of incipient invaders, and control of well-established invasive species? What species, impacts, and regions are priorities to various constituencies? How do institutions maximize the return on investment, and what is the currency of success? If or when should they declare control efforts futile and accept the continued presence or expansion of a species as inevitable? Conservation planning tools have already shown some promise in helping to resolve these questions in Hawaii and the many other places at risk from invasion globally. Although agencies such as the US Fish and Wildlife Service have adopted approaches such as structured decision modeling, there are ample opportunities to expand the use of conservation planning tools to guide action on efficient use of limited financial resources, select the most appropriate management actions among stakeholders, and determine locations of greatest management need. Conservation planning has gained considerable global traction in the past decade (Gregory et al. 2012), and such evidence-based decision-making will be critical for moving beyond the stalemates too often associated with invasive species management. Buy-in and leadership at all levels, from local to national (e.g., New Zealand's commitment to be predator free by 2050; Norton et al. 2016), will be critical to setting an agenda that crosses land ownership boundaries and brings sufficient resources to bear on control or eradication of species that have unacceptable impacts on nature and human well-being.

\section{Acknowledgments}

This article emerged from a symposium at the North American Congress for Conservation Biology in Madison, Wisconsin, in 2016. We thank the conference organizers for facilitating our lively exchange of information and ideas. We are also grateful to two anonymous reviewers for helpful comments that improved an earlier version of the manuscript. Any use of trade, firm, or product names is for descriptive purposes only and does not imply endorsement by the US government.

\section{References cited}

Alphey L. 2014. Genetic control of mosquitoes. Annual Review of Entomology 59: 205-224.

Angelo CL, Daehler CC. 2013. Upward expansion of fire-adapted grasses along a warming tropical elevation gradient. Ecography 36: 551-559.

Atkinson CT, Dusek RJ, Woods KL, Iko WM. 2000. Pathogenicity of avian malaria in experimentally-infected Hawaii Amakihi. Journal of Wildlife Diseases 36: 197-201.

Atkinson CT, Utzurrum RB, Lapointe DA, Camp RJ, Crampton LH, Foster JT, Giambelluca TW. 2014. Changing climate and the altitudinal range of avian malaria in the Hawaiian Islands: An ongoing conservation crisis on the island of Kaua'i. Global Change Biology 20: 2426-2436.

Atkinson C, Watcher-Weatherwax W, Roy K, Heller W, Keith L. 2017. A rapid diagnostic test and mobile "lab in a suitcase" platform for detecting Ceratocystis spp. responsible for Rapid 'Ōhi'a Death. Technical report no. HCSU-082. University of Hawaii. https:/dspace.lib.hawaii.edu/bitstream/10790/3025/1/Lab in a Suitcase for BAO423.pdf.

Atyame CM, Cattel J, Lebon C, Flores O, Dehecq J-S, Weill M, Gouagna LC, Tortosa P. 2015. Wolbachia-based population control strategy targeting Culex quinquefasciatus mosquitoes proves efficient under semi-field conditions. PLOS ONE 10 (art. e0119288).

Barnes I, Fourie A, Wingfield MJ, Harrington TC, McNew DL, Sugiyama LS, Luiz BC, Heller WP, Keith LM. 2018. New Ceratocystis species associated with rapid death of Metrosideros polymorpha in Hawaii. Persoonia 40: 154-181.

Blagrove MSC, Arias-Goeta C, Failloux A-B, Sinkins SP. 2012. Wolbachia strain wMel induces cytoplasmic incompatibility and blocks dengue transmission in Aedes albopictus. Proceedings of the National Academy of Sciences 109: 255-260.

Bruner, AG, Gullison RE, Rice RE, Da Fonseca GA. 2001. Effectiveness of parks in protecting tropical biodiversity. Science 291: 125-128.

Burns B, Innes J, Day T. 2012. The use and potential of pest-proof fencing for ecosystem restoration and fauna conservation in New Zealand. Pages 65-90 in Somers MJ, Hayward MW, eds. Fencing for Conservation: Restriction of Evolutionary Potential or a Riposte to Threatening Processes? Springer.

Camp RJ, Pratt TK, Gorresen, PM, Jeffrey JJ, Woodworth BL. 2010. Population trends of forest birds at Hakalau Forest National Wildlife Refuge, Hawaii. Condor 112: 196-212.

Campbell K, Donlan CJ. 2005. Feral goat eradications on islands. Conservation Biology 19: 1362-1374. 
Chiaverano LM, Holland BS. 2014. Impact of an invasive predatory lizard on the endangered Hawaiian tree snail Achatinella mustelina: A threat assessment. Endangered Species Research 24: 115-123.

Cole RJ, Litton CM, Koontz MJ, Loh RK. 2012. Vegetation recovery 16 years after feral pig removal from a wet Hawaiian forest. Biotropica 44: 463-471.

Conant P, Garcia JN, Johnson MT, Nagamine WT, Hirayama CK, Markin GP, Hill RL. 2013. Releases of natural enemies in Hawaii since 1980 for classical biological control of weeds. Pages 230-242 in Wu Y, Johnson T, Sing S, Raghu S, Wheeler G, Pratt P, Warner K, Center T, Goolsby J, Reardon R, eds. Proceedings of the XIII International Symposium on Biological Control of Weeds. September 11-16, 2011-Waikoloa, Hawaii, USA. US Forest Service.

Coordinating Group on Alien Pest Species. 2017. Tracking Awareness of and Attitudes toward Invasive Species in Hawaii. Ward Research. www.cgaps.org/wp-content/uploads/2017-CGAPS-Omnibus -ReportFINAL-101617.pdf.

Cordell S, Ostertag R, Michaud J, Warman L. 2016. Quandaries of a decadelong restoration experiment trying to reduce invasive species: Beat them, join them, give up, or start over? Restoration Ecology 24: 139-144.

Crowl TA, Crist TO, Parmenter RR, Beloversusky G, Lugo AE. 2008. The spread of invasive species and infectious disease as drivers of ecosystem change. Frontiers in Ecology and the Environment 6: 238-246.

Daehler CC, Denslow JS, Ansari S, Kuo HC. 2004. A risk-assessment system for screening out invasive pest plants from Hawaii and other Pacific islands. Conservation biology 18: 360-368.

Dawson W, et al. 2017. Global hotspots and correlates of alien species richness across taxonomic groups. Nature Ecology and Evolution 1: 1-2.

Davis MA, et al. 2011. Don't judge species on their origins. Nature 474: 153-154.

DeNitto GA, Cannon P, Eglitis A, Glaeser JA, Maffei H, Smith S. 2015. Risk and Pathway Assessment for the Introduction of Exotic Insects and Pathogens that Could Affect Hawai'i's Native Forests. General technical report no. PSW-GTR-250. U.S. Department of Agriculture, Forest Service, Pacific Southwest Research Station.

Duffy D. 2010. An Historical Analysis of Hunting in Hawai' i. Master's thesis, University of Hawai'i at Mānoa.

Duron Q, Shiels AB, Vidal, E. 2017. Control of invasive rats on islands and priorities for future action. Conservation Biology 31: 761-771.

Engeman RM, Vice DS. 2001. Objectives and integrated approaches for the control of brown tree snakes. Integrated Pest Management Reviews 6: $59-76$.

González-Muñoz N, Bellard C, Leclerc C, Meyer JY, Courchamp F. 2015. Assessing current and future risks of invasion by the "green cancer" Miconia calvescens. Biological Invasions 17: 3337-3350.

Gregory R, Failing L, Harstone M, Long G, McDaniels T, Ohlson D. 2012. Structured Decision Making: A Practical Guide to Environmental Management Choices. Wiley.

Hawaii Division of Forestry and Wildlife. 2018. Natural Area Reserve System. Hawaii Division of Forestry and Wildlife. https://dlnr.hawaii. gov/ecosystems/nars.

Henneman ML, Memmott J. 2001. Infiltration of a Hawaiian community by introduced biological control agents. Science 293: 1314-1316

Hess SC, Jacobi JD. 2011. The history of mammal eradications in Hawai and the United States associated islands of the Central Pacific. Pages 67-73 in Veitch CR, Clout MN, Towns DR, eds. Island Invasives: Eradication and Management. International Union for Conservation of Nature.

Hess SC, Jacobi JD. 2014. How much land is needed for feral pig hunting in Hawai'i? Pacific Conservation Biology 20: 54-56.

Hess SC, Muise J, Schipper J. 2015. Anatomy of an eradication effort: Removing Hawaii's illegally introduced axis deer. Wildlife Professional 9: 40-43.

Hawaii Invasive Species Council. 2019. Brown Tree Snake. https://dlnr. hawaii.gov/hisc/info/invasive-species-profiles/brown-tree-snake.

Hobbs RJ, Higgs E, Harris JA. 2009. Novel ecosystems: Implications for conservation and restoration. Trends in Ecology and Evolution 24: 599-605.
Holland JS, Kirkey JR, Reaser JK. 2018. Protecting What Matters: Stories of Success. National Invasive Species Council Secretariat, Department of the Interior.

Hollingsworth RG, Howe K, Jarvi SI. 2013. Control measures for slug and snail hosts of Angiostrongylus cantonensis, with special reference to the semi-slug Parmarion martensi. Hawaii Journal of Medicine and Public Health 72: 75-80.

Ikagawa M. 2013. Invasive ungulate policy and conservation in Hawaii. Pacific Conservation Biology 19: 270-283.

Jarvi SI, et al. 2015. Detection of Angiostrongylus cantonensis in the blood and peripheral tissues of wild hawaiian rats (Rattus rattus) by a quantitative PCR (qPCR) assay. PLOS ONE 10 (art. 0123064).

Johnson, MT. 2010. Miconia biocontrol: Where are we going and when will we get there? Proceedings of the International Miconia Conference, Keanae, Maui, Hawaii, May 4-7, 2009, Loope LL, Meyer J-Y, Hardesty BD, Smith CW, eds. Maui Invasive Species Committee and Pacific Cooperative Studies Unit, University of Hawaii at Manoa. www.hear. org/conferences/miconia2009/proceedings/2009.

Johnson, MT. 2016. Managing conflict over biological control: The case of strawberry guava in Hawaii. Pages 264-276 in Van Driesche RG, Simberloff D, Blossey B, Causton C, Hoddle MS, Wagner DL, Marks $\mathrm{CO}$, Heinz KM, Warner KD, eds, Integrating Biological Control into Conservation Practice. Wiley.

Johnston D, Viray M, Ushiroda J, Christen Whalen A, Sciulli R, Gose R, Lee R, Honda E, Park SY. 2016. Notes from the field: Outbreak of locally acquired cases of dengue fever-Hawaii, 2015. Morbity and Mortality Weekly Report 65: 34-35.

Kraus F, Duffy DC. 2010. A successful model from Hawaii for rapid response to invasive species. Journal for Nature Conservation 18: 135-141.

Leary J, Gooding J, Chapman J, Radford A, Mahnken B, Cox, LJ. 2013. Calibration of an Herbicide Ballistic Technology (HBT) helicopter platform targeting Miconia calvescens in Hawaii. Invasive Plant Science and Management 6: 292-303.

Leopold CR, Hess SC. 2016. Conversion of native terrestrial ecosystems in Hawai'i to novel grazing systems: A review. Biological Invasions 19: 161-177.

Lepczyk CA, Hess SC, Johnson ED. 2011. Hawaii and the North American model of wildlife conservation: One size fits all? The Wildlife Professional Fall 2011: 64-66.

Lockwood JL, Hoopes MF, Marchetti MP. 2013. Invasion Ecology, 2nd ed. Wiley-Blackwell.

Loope LL, Hughes RF, Meyer J-Y. 2013. Plant invasions in protected areas of tropical Pacific islands, with special reference to Hawaii. Pages 313-348 in Foxcroft L, Pysek P, Richardson D, Genovesi P, eds. Plant Invasions in Protected Areas: Patterns, Problems and Challenges. Springer.

Luck GW, Davidson P, Boxall D, Smallbone L. 2011. Relations between urban bird and plant communities and human well-being and connection to nature. Conservation Biology 25: 816-826.

McClure KM., Lawrence C, Kilpatrick AM. 2018. Land use and larval habitat increase Aedes albopictus (Diptera: Culicidae) and Culex quinquefasciatus (Diptera: Culicidae) abundance in lowland Hawaii. Journal of Medical Entomology 55: 1509-1516.

Mack RN, Simberloff D, Mark Lonsdale W, Evans H, Clout M, Bazzaz FA. 2000. Biotic invasions: Causes, epidemiology, global consequences, and control. Ecological Applications 10: 689-710.

Marchetti MP, Engstrom T. 2016. The wattle-necked softshelled turtle (Palea steindachneri), an endangered, invasive species and a conservation paradox. Conservation Biology. 30: 434-437.

Mascaro J, Hughes RF, Schnitzer SA. 2012. Novel forests maintain ecosystem processes after the decline of native tree species. Ecological Monographs 82: 221-228.

Moulton MP, Pimm SL. 1983. The introduced Hawaiian avifauna: Biogeographic evidence for competition. American Naturalist 121: 669-690.

Murcia C, Aronson J, Kattan GH, Moreno-Mateos D, Dixon K, Simberloff D. 2014. A critique of the 'novel ecosystem' concept. Trends in Ecology and Evolution 29: 548-553. 
Murdoch W, Polasky S, Wilson KA, Possingham HP, Kareiva P, Shaw R. 2007. Maximizing return on investment in conservation. Biological Conservation 139: 375-388.

Neilson BJ, Wall CB, Mancini FT, Gewecke CA. 2018. Herbivore biocontrol and manual removal successfully reduce invasive macroalgae on cora reefs. PeerJ 6: e5332 https://doi.org/10.7717/peerj.5332

Nishida GM. 2002. Hawaiian terrestrial arthropod checklist. 4th ed. Bishop Museum.

Norton DA, Young LM, Byrom AE, Clarkson BD, Lyver POB, McGlone MS, Waipara NW. 2016. How do we restore New Zealand's biological heritage by 2050? Ecological Management and Restoration 17: 170-179.

Paxton EH, Camp RJ, Gorresen PM, Crampton LH, Leonard DL, VanderWerf EA. 2016. Collapsing avian community on a Hawaiian island. Science Advances 2: e1600029.

Paxton EH, Laut M, Vetter JP, Kendall SJ. 2018. Research and management priorities for Hawaiian forest birds. Condor 120: 557-565.

Pejchar L, Mooney HA. 2009. Invasive species, ecosystem services and human well-being. Trends in Ecology and Evolution 24: 497-504.

Penniman TM, Buchanan L, Loope LL. 2011. Recent plant eradications on the islands of Maui County, Hawai'i. Pages 325-331 in Veitch CR, Clout MN, Towns DR, eds. Island Invasives: Eradication and Management. International Union for Conservation of Nature.

Peterson AT. 2003. Predicting the geography of species' invasions via ecological niche modeling. Quarterly Review of Biology 78: 419-433.

Pimentel D, Zuniga R, Morrison D. 2005. Update on the environmental and economic costs associated with alien-invasive species in the United States. Ecological Economics 52: 273-288.

Reimer NJ. 2002. Review and permit process for biological control releases in Hawaii. Pages 86-90 in Smith CW, Denslow J, Hight S, eds. Proceedings of Workshop on Biological Control of Native Ecosystems in Hawaii. Pacific Cooperative Studies Unit, University of Hawaii at Manoa, Department of Botany, Technical Report 129. www.hear.org/ pcsu/techreports/129.

Sakai AK, et al. 2001. The population biology of invasive species. Annual Review of Ecology and Systematics 32: 305-332.

Shiels AB, Bogardus T, Rohrer J, Kawelo K. 2019. Effectiveness of snap and A24-automated traps and broadcast anticoagulant bait in suppressing commensal rodents in Hawaii. Human-Wildlife Interactions 13: 226-237.

Shwiff SA, Gebhart K, Kirkpatrick KN, Shwiff SS. 2010. Potential economic damage from introduction of brown tree snakes, Boiga irregularis (Reptilia: Colubridae), to the islands of Hawai'i. Pacific Science 64: $1-10$.

Simberloff D, Von Holle B. 1999. Positive interactions of nonindigenous species: Invasional meltdown? Biological Invasions 1: 21-32.

Smith CW. 2002. Forest pest biological control program in Hawaii. Pages 91-102 in Smith CW, Denslow J, Hight S, eds. Proceedings of Workshop on Biological Control of Native Ecosystems in Hawaii. Technical report no. 129. Pacific Cooperative Studies Unit, University of Hawaii, Honolulu. www.botany.hawaii.edu/faculty/duffy/techr/129.pdf.

Truitt AM, Granek EF, Duveneck MJ, Goldsmith KA, Jordan MP, Yazzie KC. 2015. What is novel about novel ecosystems: Managing change in an ever-changing world. Environmental Management 55: $1217-1226$.
Trujillo EE, Kadooka C, Tanimoto V, Bergfeld S, Shishido G, Kawakami G. 2001. Effective biomass reduction of the invasive weed species banana poka by Septoria leaf spot. Plant Disease 85: 357-361.

van Driesche RG, et al. 2016. Cases of biological control restoring natural systems. Pages 208-246 in van Driesche RG, Simberloff D, Blossey B, Causton C, Hoddle M, Marks CO, Heinz KM, Wagner DL, Warner KD, eds. Integrating Biological Control into Conservation Practice. Wiley Blackwell.

Vaughn NR, Asner GP, Brodrick PG, Martin RE, Heckler JW, Knapp DE, Hughes RF. 2018. An approach for high-resolution mapping of Hawaiian Metrosideros forest mortality using laser-guided imaging spectroscopy. Remote Sensing 10: 502.

Vilà M, Espinar JL, Hejda M, Hulme PE, Jarošík V, Maron JL, Pergl J, Schaffner U, Sun Y, Pyšek P. 2011. Ecological impacts of invasive alien plants: A meta-analysis of their effects on species, communities and ecosystems. Ecology Letters 14: 702-708.

Vitousek PM, Loope LL, Stone CP. 1987. Introduced species in Hawaii: Biological effects and opportunities for ecological research. Trends in Ecology and Evolution 2: 224-227.

Wagner WL, Herbst DR, Sohmer SH. 1999. Manual of the Flowering Plants of Hawaii, revised edition. Bishop Museum. Special publication no. 97.

Warner KD, Kinslow F. 2013. Manipulating risk communication: Value predispositions shape public understandings of invasive species science in Hawaii. Public Understanding of Science 22: 203-218.

Watson JS. 1961. Feral rabbit populations on Pacific Islands. Pacific Science 11: 591-593.

Wehr NH, Hess SC, Litton CM. 2018. Biology and impacts of Pacific Island invasive species 14: Sus scrofa, the feral pig (Artiodactyla: Suidae). Pacific Science 72: 177-198.

Woodworth BL, et al. 2005. Host population persistence in the face of introduced vector-borne diseases: Hawaii amakihi and avian malaria. Proceedings of the National Academy of Sciences 102: 1531-1536.

Wostenberg DJ, Hopken MW, Shiels AB, Piaggio AJ. 2019. Using DNA to identify the source of invasive mongoose, Herpestes auropuncatus (Carnivora: Herpestidae) captured on Kaua'i. Pacific Science 73: 215-223.

Yamamoto MN, Tagawa AW. 2000. Hawai'i's Native and Exotic Freshwater Animals. Mutual Publishing.

Young LC, VanderWerf EA, Lohr MT, Miller CJ, Titmus AJ, Peters D, Wilson L. 2013. Multi-species predator eradication within a predatorproof fence at Ka'ena Point, Hawai'i. Biological Invasions 15: 2627-2638.

Liba Pejchar (liba.pejchar@colostate.edu) is a conservation biologist and associate professor at Colorado State University, in Fort Collins. Christopher Lepczyk is a professor and wildlife biologist and Jean Fantle-Lepczyk is an assistant research professor at Auburn University, in Auburn, Alabama. Steven Hess is a wildlife biologist with the US Geological Survey Pacific Islands Ecosystems Research Station, in Hawaii Volcanoes National Park, Hawaii. Tracy Johnson is a research entomologist with the US Department of Agriculture Forest Service, in Hawaii Volcanoes National Park, Hawaii. Christina Leopold is a wildlife research analyst with the University of Hawaii in Hilo. Michael P. Marchetti is the Fletcher Jones Professor of Ecology at St. Mary's College of California, in Moraga. Katherine McClure was a PhD candidate at the University of California Santa Cruz when this project began and is now a postdoctoral fellow at Cornell University in Ithaca, New York. Aaron Shiels is a research biologist at the USDA Animal and Plant Health Inspection Service National Wildlife Research Center in Fort Collins, Colorado. 